Original article

\title{
In vitro biocompatibility testing of different base materials used for elevation of proximal subgingival margins using human gingival epithelial cells
}

\author{
Hoda S. Ismail ${ }^{1)}$, Ashraf I. Ali ${ }^{1)}$, and Franklin Garcia-Godoy ${ }^{2,3)}$ \\ Operative Dentistry Department, Faculty of Dentistry, Mansoura University, Mansoura, Egypt \\ 2) Department of Bioscience Research, College of Dentistry, University of Tennessee Health Science Center, Memphis, TN, USA \\ ${ }^{3)}$ The Forsyth Institute, Cambridge, MA, USA
}

\begin{abstract}
Purpose: To analyze the biological effects of four base materials used for elevation of proximal subgingival margins on gingival epithelial cells.

Methods: Twenty-eight specimens for each of the four base materials (total 112 specimens) were used: resin-modified glass ionomer (RMGI), glass hybrid (HV-GIC), flowable bulk fill resin composite (Bulk Flow) and bioactive ionic resin (Activa). Proximal enamel and root dentin were used as controls. Gingival epithelial cell viability was calculated after direct incubation on all four types of material for either $24 \mathrm{~h}$ or $72 \mathrm{~h}$ using both the methyl tetrazolium and trypan blue dye exclusion assays. Data were analyzed statistically using one-way analysis of variance, Tukey post hoc test and independent sample $t$-test $(P<0.05)$.

Results: Cell viability values in both assays showed significant differences among the study groups. Bulk Flow showed the highest values, followed in order by Activa and the control groups. Both HV-GIC and RMGI had the lowest values. Cell viability in all of the study groups was higher after incubation for $72 \mathrm{~h}$ than after $24 \mathrm{~h}$.

Conclusion: In terms of biocompatibility with epithelial tissues, bulk fill resin composite appears to be most suitable, followed by bioactive composite, for subgingival placement than glass ionomer-based materials, especially that containing 2-hydroxy-ethyl methacrylate.
\end{abstract}

Keywords: bioactive materials, biocompatibility, bulk fill composite, cell viability, gingival epithelial cells, glass ionomer

\section{Introduction}

Proximal posterior cavities extending below the cement-enamel junction (CEJ) and cavity margins located beneath gingival tissues represent a very common clinical situation [1]. Besides the challenges encountered during restoration of such defects and bonding to dentin/cementum margins [1], the restorative material employed is in direct contact with gingival epithelial tissues, which may result in direct or indirect interactions [2]. In a normal healthy situation, junctional epithelial cells are attached to tooth structure by hemi-desmosomes and form a tight seal between the gingiva and the tooth surface $[2,3]$. Consequently, in clinical situations, attachment of gingival epithelial cells to restorative materials placed below the gingiva is desirable for restoring the same seal [2], otherwise, bacterial invasion and colonization may occur, leading to periodontal problems [3].

Subgingival proximal cavities are usually restored using either an open sandwich technique with glass ionomer-based materials or deep margin elevation using different categories of resin composites [4,5]. Regardless of the type of restorative material, a favorable biologic response of any material placed subgingivally on gingival epithelial cells is crucial for long-term periodontal success. Cell culture studies are frequently used for evaluation of in vitro biocompatibility and cytotoxicity of restorative

Correspondence to Dr. Hoda Saleh Ismail, Operative Dentistry Department, Faculty of Dentistry, Mansoura University, Algomhoria Street, PO Box 35516 Mansoura, Aldakhlia 35931, Egypt Email: hoda_saleh@mans.edu.eg

Color figures can be viewed in the online issue at J-STAGE.

doi.org/10.2334/josnusd.21-0393

DN/JST.JSTAGE/josnusd/21-0393 materials [6]. Furthermore, colorimetric assays, such as the methyl tetrazolium (MTT) and trypan blue dye exclusion (TBDE) assays, have been used extensively for quantitative assessment of both cell viability and cytotoxicity in vitro, as they are considered simple, rapid and precise [6,7].

Despite extensive studies of the interactions of glass ionomer-based or resin-based materials with dental pulp cells [8-11], employing mechanical, esthetic and biological approaches, there has been a significant lack of research on the periodontal biocompatibility of these materials with gingival epithelial cells when used subgingivally. Therefore, this study evaluated and compared the viability of oral gingival epithelial cells after being in direct contact with four different base materials used for elevation of proximal subgingival margins. The null hypotheses were: (1) the type of material would not significantly affect the viability of oral gingival epithelial cells; (2) there would be no significant difference between the viability of gingival epithelial cells incubated on each material for different periods.

\section{Materials and Methods}

\section{Materials}

Four commercially available restorative materials were tested: resinmodified glass ionomer (Fuji II LC, GC Corp., Tokyo, Japan) (RMGI), glass hybrid (Equia Forte HT Fil, GC Corp.) (HV-GIC), flowable bulk fill resin composite (Tetric EvoFlow Bulk Fill, Ivoclar Vivadent, Amherst, NY, USA) (Bulk Flow) and bioactive ionic resin (Activa Bioactive Restorative, Pulpdent Corp., Watertown, MA, USA) (Activa). Table 1 gives a detailed description of the materials.

\section{Specimen preparation}

Preparation of restorative material specimens

A total of 112 specimens ( 28 specimens of each restorative material) were prepared in a specially designed mold $(6.0 \mathrm{~mm}$ diameter $\times 1.5 \mathrm{~mm}$ depth$)$. The specimens were prepared by a standardized method in which the material was pressed into the mold between two glass slides covered with Mylar strips (SS White, Lakewood, NJ, USA) [2]. All the materials were mixed and dispensed in accordance with the manufacturers' instructions.

The surfaces of the RMGI, Bulk Flow and Activa specimens were cured on both sides, as recommended by the manufacturers, with a LED curing light (Elipar Deep Cure, 3M ESPE, St. Paul, MN, USA) operating at $1,000 \mathrm{~mW} / \mathrm{cm}^{2}$. The curing light intensity was checked periodically after curing of every 5 specimens with a radiometer (Radiometer 100, Demetron Research Corp., Danbury, CT, USA).

\section{Preparation of control specimens}

In order to mimic adhesion to human tooth-like biological material, human tooth proximal enamel and root dentin specimens were used as controls.

Twenty-eight sound human lower molars recently extracted due to periodontal disease were included in this study; they were selected if the height of the proximal enamel and width of the root dentin were at least $5 \mathrm{~mm}$. The selected teeth were examined under a stereomicroscope to confirm they were free of caries and cracks, then cleaned with an ultrasonic scaler to remove soft tissue and calculus deposits and stored in $0.1 \%$ thymol solution until used. The teeth were collected with the approval of the Ethics Committee (No. A 26100221).

Twenty-eight rectangular slabs of both proximal enamel $(n=28)$ and root dentin $(n=28)$ were prepared with a length of $5.5 \mathrm{~mm}$, a width of 5.0 
Table 1 Materials used in the study

\begin{tabular}{|c|c|c|c|c|}
\hline Material & Type & Manufacturer & Composition & Lot number \\
\hline Fuji II LC & $\begin{array}{l}\text { Resin- modified glass } \\
\text { ionomer }\end{array}$ & GC Corp., Tokyo, Japan & $\begin{array}{l}\text { powder: } 100 \% \text { strontium fluoroalumino silicate glass } \\
\text { liquid: } 35 \% \text { HEMA, } 25 \% \text { distilled water, } 24 \% \text { polyacrylic acid, } 6 \% \text { tartaric acid and } \\
0.10 \% \text { camphorquinone }\end{array}$ & 2010071 \\
\hline Equia Forte HT Fil & Glass hybrid & GC Corp. & $\begin{array}{l}\text { powder: strontium fluoroalumino-silicate glass (including highly reactive small parti- } \\
\text { cles), polyacrylic acid powder liquid: polyacrylic acid, polycarboxylic acid, tartaric acid }\end{array}$ & 2002151 \\
\hline Tetric EvoFlow Bulk fill & $\begin{array}{l}\text { Flowable bulk fill resin } \\
\text { composite }\end{array}$ & $\begin{array}{l}\text { Ivoclar Vivadent, Amherst, } \\
\text { NY, USA }\end{array}$ & $\begin{array}{l}\text { Bis-GMA, Bis-EMA, UDMA, Ivocerin, barium glass, ytterbium trifluoride, mixed } \\
\text { oxide, silicon dioxide }\end{array}$ & Y35353 \\
\hline $\begin{array}{l}\text { Activa Bioactive } \\
\text { Restorative }\end{array}$ & $\begin{array}{l}\text { Bioactive resin and } \\
\text { bioactive glass fillers }\end{array}$ & $\begin{array}{l}\text { Pulpdent Corp., Watertown, } \\
\text { MA, USA }\end{array}$ & $\begin{array}{l}\text { powder: diurethane dimethacrylate, bis ( } 2 \text {-[methacryloyloxy] ethyl) phosphate, barium } \\
\text { glass, ionomer glass, sodium fluoride, colorants } \\
\text { liquid: polyacrylic acid/maleic acid copolymer }\end{array}$ & 190619 \\
\hline
\end{tabular}

HEMA, 2-hydroxy-ethyl methacrylate; Bis-EMA, bisphenol-A polyethylene glycol diether dimethacrylate; Bis-GMA, bisphenol A-glycidyl methacrylate; UDMA, urethane dimethacrylate
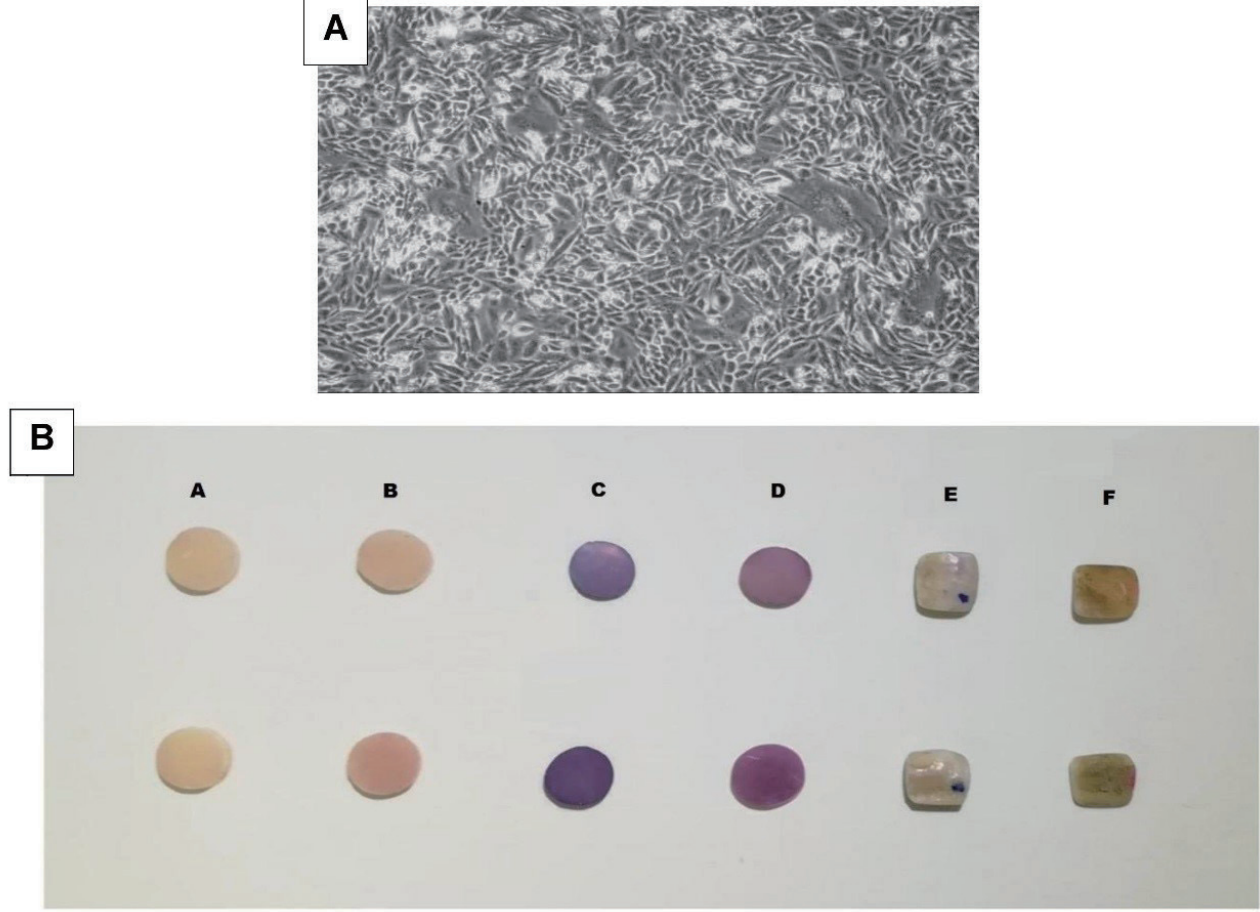

Fig.1 A: light micrograph of gingival epithelial cells used in the study at $80 \%$ confluence under an inverted microscope $(\times 10)$. B: Representative specimens of all groups after the MTT assay: upper row after $24 \mathrm{~h}$ of incubation, and lower row after $72 \mathrm{~h}$. A: RMGI, B: HV-GIC, C: Bulk Flow, D: Activa, E: Proximal enamel, F: Root dentin

$\mathrm{mm}$ and a thickness of about 1.0-1.5 $\mathrm{mm}$ using a diamond disk (Shanghai Luk Company Ltd., Shanghai, P. R. China) under copious amounts of water coolant. On each specimen, the outer surface to be tested was labeled.

All specimens (restorative materials and control specimens) were cleaned ultrasonically in $70 \%$ ethanol, each for $15 \mathrm{~min}$, then rinsed in ultrapure water for $10 \mathrm{~min}$, with further ultraviolet sterilization of both surfaces using UV lamps (Light Sources Inc., Orange, CT, USA) for 20 min before testing. There were four restorative materials groups and two control groups (proximal enamel and root dentin). Half of each group was tested using either the MTT assay $(n=14)$ or the TBDE assay $(n=14)$. Each of the assay specimens were further subdivided into two subgroups, each with 7 specimens, to be tested after incubation for either $24 \mathrm{~h}$ or 72 h. All preparation procedures were performed by a single operator using a loupe with a magnification of $\times 4$ (Amtech, Wenzhou, P. R. China).

\section{Gingival epithelial cell culture}

The cells employed were a human gingival epithelial cell line obtained from Nawah Scientific Center (Cairo, Egypt). The cells were cultured in Dulbecco's Modified Eagle Medium (Sigma-Aldrich GmbH, Schnelldorf, Germany) with $10 \%$ fetal bovine serum (Thermo Fisher Scientific, Waltham, MA, USA) and 1\% penicillin-streptomycin (Thermo Fisher Scientific) and maintained at $37^{\circ} \mathrm{C}$ in an incubator (SHEL LAB, Sheldon Manufacturing, Inc., Cornelius, OR, USA) supplied with 5\% carbon dioxide for at least one week. Fresh serum-free culture medium with a composition reported previously by Forster et al. [12] was added to the cells three times per week until the cells reached $70-80 \%$ confluence (Fig. $1 \mathrm{~A})$, and cell confluence was estimated qualitatively using an inverted microscope at $\times 10$ (Olympus, Tokyo, Japan) by observing the space occupied by the cells and their colonies in the flask (Greiner Bio-One North America Inc., Monroe, NC, USA).

Before each experiment, the cells were washed with phosphate-buffered saline (PBS) and trypsinized with $0.05 \%$ trypsin-EDTA (Thermo Fisher Scientific). Cell numbers were counted using a cell analyzer (Guava Muse Cell Analyzer, Luminex Corp., Austin, TX, USA).

\section{Cell viability testing}

Two hundred microliters of cell suspension at a density of $10^{3}$ cells/well was seeded onto each specimen in a 96-well culture plate (Greiner BioOne North America Inc.). The cells were allowed to adhere to the surface of the specimens for $45 \min (10 \mu \mathrm{L}$ of cell suspension) before adding the rest of the culture medium $(190 \mu \mathrm{L})$ [3]. A pilot study conducted before testing had shown that 45 min was a suitable time to allow cell adhesion and prevent cell suspension dehydration. All culture plates were then incubated in $5 \% \mathrm{CO}_{2}$ at $37 \pm 1^{\circ} \mathrm{C}, 95 \%$ humidity for either $24 \mathrm{~h}$ or $72 \mathrm{~h}$.

\section{MTT assay}

The MTT assay was performed using a Vybrant MTT Cell Proliferation Assay Kit (V-13154, Molecular Probes Inc., Thermo Fisher Scientific). 
Table 2 Multiple comparisons of mean \pm SD MTT absorbance $\left[\mathrm{OD}_{570}\right]$ values for all 24-h subgroups, and percentage value of (absorbance of each material / mean absorbance value of each control)

\begin{tabular}{ll}
\hline Material & Absorbance $\left(\mathrm{OD}_{570}\right)$ \\
\hline RMGI & $1.23 \pm 0.16^{\mathrm{c}}\left(66.64 \%^{*}, 64.89 \%^{* *}\right)$ \\
HV-GIC & $1.37 \pm 0.09^{\mathrm{c}}\left(74.05 \%^{*}, 72.10 \%^{* *}\right)$ \\
Bulk Flow & $2.24 \pm 0.26^{\mathrm{a}}\left(121.55 \%^{*}, 118.35 \%^{* *}\right)$ \\
Activa & $2.08 \pm 0.10^{\mathrm{b}}\left(112.51 \%^{*}, 109.55 \%^{* *}\right)$ \\
Proximal enamel & $1.85 \pm 0.23^{\mathrm{b}}$ \\
Root dentin & $1.90 \pm 0.17^{\mathrm{b}}$ \\
\hline
\end{tabular}

RMGI, resin-modified glass ionomer; HV-GIC; highly viscous glass ionomer cement; Bulk Flow, flowable bulk fill resin composite; Activa, Activa Bioactive Restorative. Groups identified with the same superscripted letters were not significantly different (Tukey HSD; $P<0.05$ ). *Percentage value of (material OD / mean OD of proximal enamel $24 \mathrm{~h}$ subgroup). **Percentage value of (material OD / mean OD of root dentin $24 \mathrm{~h}$ subgroup)
Table 3 Multiple comparisons of mean \pm SD MTT absorbance $\left(\mathrm{OD}_{570}\right)$ values for all 72-h subgroups, and percentage values of (absorbance of each material / mean absorbance value of each control)

\begin{tabular}{ll}
\hline Material & Absorbance $\left(\mathrm{OD}_{570}\right)$ \\
\hline RMGI & $1.36 \pm 0.23^{\mathrm{c}}\left(74.30^{*}, 63.29 \%^{* *}\right)$ \\
HV-GIC & $1.52 \pm 0.29^{\mathrm{b}}\left(82.76 \%^{*}, 70.50 \% * *\right)$ \\
Bulk Flow & $2.54 \pm 0.20^{\mathrm{a}}\left(138.19 \%^{*}, 117.72 \%^{* *}\right)$ \\
Activa & $2.29 \pm 0.11^{\mathrm{a}}\left(124.68 \%^{*}, 106.2 \%^{* *}\right)$ \\
Proximal enamel & $1.84 \pm 0.28^{\mathrm{b}}$ \\
Root dentin & $2.16 \pm 0.29^{\mathrm{a}}$ \\
\hline
\end{tabular}

Groups identified with the same superscripted letters were not significantly different (Tukey HSD; $P$
$0.05)$ *Percentage value of (material $\mathrm{OD} /$ mean $\mathrm{OD}$ of proximal enamel $72 \mathrm{~h}$ subgroup). ** Percentage value of (material $\mathrm{OD} /$ mean $\mathrm{OD}$ of root dentin $72 \mathrm{~h}$ subgroup)

Table 4 Independent sample $t$-test for absorbance values of 24-h subgroups versus 72-h subgroups evaluated using MTT assay

\begin{tabular}{|c|c|c|c|c|c|c|c|c|c|}
\hline \multirow{3}{*}{ Material } & \multicolumn{3}{|c|}{$\begin{array}{c}\text { Levene's test for } \\
\text { equality of variances }\end{array}$} & \multicolumn{4}{|c|}{$t$-test for equality of means } & & \\
\hline & \multirow[t]{2}{*}{$F$} & \multirow[t]{2}{*}{ Sig. } & \multirow[t]{2}{*}{$t$} & \multirow[t]{2}{*}{$\mathrm{df}$} & \multirow{2}{*}{$\begin{array}{c}\text { Sig. } \\
\text { (2-tailed) }\end{array}$} & \multirow{2}{*}{$\begin{array}{c}\text { Mean } \\
\text { difference }\end{array}$} & \multirow{2}{*}{$\begin{array}{l}\text { Std. error } \\
\text { difference }\end{array}$} & \multicolumn{2}{|c|}{$\begin{array}{l}95 \% \text { Confidence interval } \\
\text { of the difference }\end{array}$} \\
\hline & & & & & & & & Lower & Upper \\
\hline RMGI & 0.603 & 0.452 & 1.243 & 12 & 0.238 & 0.13486 & 0.10853 & 0.37133 & 0.10162 \\
\hline HV-GIC & 3.525 & 0.085 & 1.330 & 12 & 0.208 & 0.15300 & 0.11505 & 0.40366 & 0.09766 \\
\hline Bulk Flow & 0.872 & 0.369 & 2.294 & 12 & 0.041 & 0.29214 & 0.12734 & 0.56959 & 0.01469 \\
\hline Activa & 0.127 & 0.728 & 3.530 & 12 & 0.004 & 0.21150 & 0.05992 & 0.34205 & 0.08095 \\
\hline Proximal enamel & 1.013 & 0.334 & 0.056 & 12 & 0.957 & 0.00779 & 0.14015 & 0.29758 & 0.31316 \\
\hline Root dentin & 1.753 & 0.210 & 1.993 & 12 & 0.070 & 0.26050 & 0.13074 & 0.54535 & 0.02435 \\
\hline
\end{tabular}

MTT is a rapid colometric assay that determines the number of living cells by measuring their ability to reduce MTT dye to insoluble purple formazan by succinate dehydrogenase present within the mitochondria [12]. The MTT stock solution was prepared by sonication of $5 \mathrm{mg} / \mathrm{mL} \mathrm{MTT} \mathrm{in}$ PBS and stored at $-20^{\circ} \mathrm{C}$. After cell incubation, the medium was carefully aspirated and replaced with fresh culture medium and only $10 \mu \mathrm{L}$ of MTT solution was added to each well. The plates were then incubated at $37^{\circ} \mathrm{C}$ for $4 \mathrm{~h}$. After incubation, $100 \mu \mathrm{L}$ of MTT solvent (sodium dodecyl sulfate in $\mathrm{HCl}$ ) was added to each well to solubilize the crystallized dye, followed by wrapping the plate with foil and shaking on an orbital shaker for $15 \mathrm{~min}$. The dye absorbance was read within $1 \mathrm{~h}$ in a micro-plate reader (Biotek Instruments, Winooski, VT, USA) at $570 \mathrm{~nm}\left(\mathrm{OD}_{570}\right)$. The average of five measurements was taken from each disc.

\section{TBDE assay}

This assay was conducted using trypan blue dye (T8154, Sigma-Aldrich $\mathrm{GmbH}$ ), a vital dye that interacts selectively with dead cells having damaged membranes. In contrast, live cells remain unstained [13].

After $24 \mathrm{~h}$ of incubation, the adherent cells were washed with PBS and trypsinized to dissociate the cell clusters from the specimens, then re-suspended in fresh serum-free culture medium to prevent background staining. The cell suspension was mixed by pipetting several times to obtain a uniform single-cell suspension [14], then $20 \mu \mathrm{L}$ of freshly prepared $0.4 \%$ trypan blue dye solution was added and well mixed to $20 \mu \mathrm{L}$ of the cell suspension. The cell count was then determined using a hemocytometer (Thermo Fisher Scientific) with $10 \mu \mathrm{L}$ of the trypan blue-cell suspension under an inverted light microscope $[13,14]$ within 5 min after staining. Both the unstained (viable) and stained (non-viable) cells were counted separately. The total number of viable cells per $\mathrm{mL}$ was calculated by multiplying the total number of viable cells by 2 (the dilution factor for trypan blue). The total number of cells (vital + non-vital) per $\mathrm{mL}$ was calculated by summing the total number of viable and non-viable cells and multiplying by 2 . The cell viability rate was calculated using the formula: viable cells $\%=$ (total number of viable cells per $\mathrm{mL} /$ total number of cells per $\mathrm{mL}) \times 100$.

The examiner performing the tests was blinded to the specimen preparation steps. Each experiment was repeated 3 times and the averages were taken for each subgroup to verify the reproducibility of the results.

\section{Statistical analysis}

Sample size calculation

The sample size for this study was calculated beforehand using the $\mathrm{G}^{*}$ Power program ( $\mathrm{G}^{*}$ Power Ver. 3.0.10, Kiel, Germany) according to
Forster et al. [12]. The total sample size of 168 specimens achieved $80 \%$ power (equal to type II error); type I error $(\alpha)$ was 0.05 .

\section{Statistical methods}

All data were analyzed statistically using SPSS (SPSS version 20, IBM, Chicago, IL, USA). Shapiro-Wilk test showed that both absorbance values $\left(\mathrm{OD}_{570}\right)$ and percentage viability per $\mathrm{mL}$ had a normal distribution and the homogeneity of variance was tested using Levene's test. Therefore, parametric tests were used to compare the study subgroups; data were presented as the mean \pm standard deviation (SD) for each subgroup. Oneway analysis of variance (ANOVA) was used to compare the absorbance and percentage viability values for all 24-h and 72-h subgroups; when significant differences were detected, a pairwise comparison was performed using Tukey post hoc test (at $P<0.05$ ). The absorbance and percentage viability values for the 24 -h subgroups versus the 72 -h subgroups were compared using independent sample $t$-test (at $P<0.05$ ).

\section{Results}

\section{MTT assay results}

One-way ANOVA for the 24-h subgroups demonstrated statistical significance $(P<0.001)$. The mean absorbance values, SD and percentage absorbance values for each material relative to the mean absorbance values for each control in the 24-h subgroups are presented in Table 2. Pairwise comparisons revealed that Bulk Flow had the highest absorbance values, followed by the Activa and control subgroups, whose absorbance values did not differ significantly from each other $(P>0.05)$. The lowest values were shown by the HV-GIC and RMGI subgroups, whose absorbance values did not differ significantly from each other $(P>0.05)$.

One-way ANOVA for the 72-h subgroups demonstrated statistical significance $(P<0.001)$. The mean absorbance values, SD and percentage of absorbance values for each material relative to the mean absorbance values for each control in the 72-h subgroups are presented in Table 3. Pairwise comparisons revealed that Bulk Flow, Activa and root dentin had the highest absorbance values, followed by the proximal enamel and HV-GIC subgroups. The lowest absorbance was shown by the RMGI subgroup.

Table 4 presents the results of the independent sample $t$-test used to compare the 24-h and 72-h absorbance values for each group. Significant differences were evident between the Bulk Flow and Activa subgroups $(P$ $<0.05$ ); however, there were no significant differences between the 24-h and 72-h absorbance values for the other restorative materials or control groups $(P>0.05)$. Representative specimens from all groups after the MTT assay (after incubation for $24 \mathrm{~h}$ and $72 \mathrm{~h}$ ) are presented in Fig. 1B. 
Table 5 Multiple comparisons of mean \pm SD percentage cell viability $/ \mathrm{mL}$ for all 24-h subgroups evaluated using the TBDE assay

\begin{tabular}{ll}
\hline Material & Viability $\%$ \\
\hline RMGI & $47.63 \pm 6.5^{\mathrm{c}}$ \\
HV-GIC & $49.46 \pm 3.09^{\mathrm{c}}$ \\
Bulk Flow & $63.82 \pm 4.68^{\mathrm{a}}$ \\
Activa & $60.44 \pm 4.17^{\mathrm{ab}}$ \\
Proximal enamel & $53.28 \pm 4.41^{\mathrm{bc}}$ \\
Root dentin & $57.25 \pm 3.51^{\mathrm{ab}}$ \\
\hline Groups identified with the same superscripted letters were not significantly different \\
(Tukey HSD; $P<0.05$ ).
\end{tabular}

Table 6 Multiple comparisons of mean \pm SD percentage cell viability $/ \mathrm{mL}$ for all 72-h subgroups evaluated using the TBDE assay

\begin{tabular}{lc}
\hline Material & Viability $\%$ \\
\hline RMGI & $49.12 \pm 9.8^{\mathrm{c}}$ \\
HV-GIC & $50.97 \pm 4.45^{\mathrm{c}}$ \\
Bulk Flow & $66.48 \pm 5.57^{\mathrm{a}}$ \\
Activa & $61.48 \pm 4.82^{\mathrm{ab}}$ \\
Proximal enamel & $55.27 \pm 3.90^{\mathrm{bc}}$ \\
Root dentin & $62.48 \pm 5.26^{\mathrm{ab}}$ \\
\hline Groups identified with the same superscripted letters were not significantly different \\
(Tukey HSD; $P<0.05$ ).
\end{tabular}

Table 7 Independent sample $t$-test of percentage cell viability/ $\mathrm{mL}$ for 24 -h subgroups versus 72 -h subgroups evaluated using the TBDE assay

\begin{tabular}{|c|c|c|c|c|c|c|c|c|c|}
\hline \multirow{3}{*}{ Material } & \multicolumn{3}{|c|}{$\begin{array}{l}\text { Levene's test for } \\
\text { equality of variances }\end{array}$} & \multicolumn{4}{|c|}{$t$-test for equality of means } & & \\
\hline & \multirow[t]{2}{*}{$F$} & \multirow[t]{2}{*}{ Sig. } & \multirow[t]{2}{*}{$t$} & \multirow[t]{2}{*}{ df } & \multirow{2}{*}{$\begin{array}{c}\text { Sig. } \\
\text { (2-tailed) }\end{array}$} & \multirow{2}{*}{$\begin{array}{c}\text { Mean } \\
\text { difference }\end{array}$} & \multirow{2}{*}{$\begin{array}{l}\text { Std. error } \\
\text { difference }\end{array}$} & \multicolumn{2}{|c|}{$\begin{array}{l}95 \% \text { Confidence interval } \\
\text { of the difference }\end{array}$} \\
\hline & & & & & & & & Lower & Upper \\
\hline RMGI & 0.588 & 0.458 & 0.332 & 12 & 0.746 & 1.48000 & 4.46334 & 11.20478 & 8.24478 \\
\hline HV-GIC & 1.014 & 0.334 & 0.738 & 12 & 0.475 & 1.51286 & 2.05055 & 5.98063 & 2.95491 \\
\hline Bulk Flow & 0.009 & 0.924 & 0.966 & 12 & 0.353 & 2.65857 & 2.75128 & 8.65310 & 3.33596 \\
\hline Activa & 0.142 & 0.713 & 0.417 & 12 & 0.684 & 1.00000 & 2.39652 & 6.22158 & 4.22158 \\
\hline Proximal enamel & 0.266 & 0.615 & 0.788 & 12 & 0.446 & 1.96571 & 2.49554 & 7.40302 & 3.47159 \\
\hline Root dentin & 1.847 & 0.199 & 2.208 & 12 & 0.047 & 5.22857 & 2.36750 & 10.38691 & 0.07024 \\
\hline
\end{tabular}

\section{TBDE assay results}

One-way ANOVA for the 24-h subgroups demonstrated statistical significance $(P<0.001)$. The mean percentage viability per $\mathrm{mL}$ values and $\mathrm{SD}$ for the 24-h subgroups are presented in Table 5. Pairwise comparisons revealed that Bulk Flow had the highest percentage viability, followed by the Activa, root dentin and proximal enamel subgroups, which showed no significant differences in percentage viability among them $(P>0.05)$. The lowest values were found in the HV-GIC and RMGI subgroups, which showed no significant difference in percentage viability between them $(P$ $>0.05)$.

One-way ANOVA for the 72-h subgroups demonstrated statistical significance $(P<0.001)$. The mean percentage viability per $\mathrm{mL}$ values and SD for the 72-h subgroups are presented in Table 6. Pairwise comparisons revealed that Bulk Flow, root dentin, and then Activa had the highest percentage viability values among the subgroups, followed by proximal enamel and HV-GIC. The lowest absorbance was shown by the RMGI subgroup.

The results of independent sample $t$-test used to compare the 24-h and 72-h percentage viability values for each group are presented in Table 7 . Significant differences were found among the root dentin subgroups $(P<$ 0.05 ); on the other hand, there were no significant differences between the 24-h and 72-h percentage viability values for any of the restorative materials or proximal enamel $(P>0.05)$.

\section{Discussion}

It has been reported that long junctional epithelium (LJE), which usually forms after the restoration of deep proximal cavities, has less efficient sealing capacity than the normal JE [15]. This compromised epithelial sealing could be strengthened by enhanced cell adhesion and spreading behavior [16]. Therefore, the rationale of the present study was to investigate the possible biological and cytotoxic effects of the tested materials, thus possibly indicating the quality of the gingival epithelial seal around them.

The four tested materials were selected on the basis of both the open sandwich technique and the concept of cervical margin relocation $[4,5]$. The open sandwich technique using RMGI and HV-GIC for elevation of the gingival margins is reported to have acceptable long-term outcomes [17]. On the other hand, cervical margin relocation includes the use of a flowable resin composite base to raise the proximal gingival margin [18]. Bulk fill resin composites with different chemical compositions have been developed to reduce polymerization shrinkage stress. In addition, they can be placed in layers up to $4 \mathrm{~mm}$ in thickness and cured in a single step [19]. Thus, they can be applied quickly and save chair time, especially when used for deep and large cavities [19]. This was the reason for the use of a flowable bulk fill material in this study.
Bioactive restorative materials are a relatively new category that react to $\mathrm{pH}$ changes in the mouth to maintain the chemical integrity of the tooth structure. Activa bioactive restorative is one such type [10]. Benetti et al. [10] have reported that this material shows flexural strength and fracture toughness comparable to those of flowable and bulk-fill resin composites. It was therefore selected as a base material for the present study.

Although previous studies of material biocompatibility have used either cell culture plates [12] or bovine enamel [2] as controls, the control materials in this study were human proximal enamel and root dentin in order to approximate the cell adhesion that might occur clinically. However, this restricted the size of the control specimens and affected the size of the test materials' discs. Therefore, uniform discs $6 \mathrm{~mm}$ in diameter were prepared. The 96-well culture plates had a diameter of $6.4 \mathrm{~mm}$ for each well; they were used to ensure that the cells were seeded on the surface of the material disc and not on the base of each well.

The discs of the various materials were tested after they had been lightcured or left to set against the band without further finishing or polishing of their surfaces; in addition, no resin top coat was added to the surface of the glass ionomer specimens to simulate the clinical scenario when elevating the proximal subgingival margin. An immortalized cell line instead of primary cells was used in this study due to its easier maintenance and greater reproducibility in culture [20]; this also minimized inter-batch variability [2].

Usually, biocompability and cytotoxicity are assessed using cellular reactions to eluates of the materials $[21,22]$. However, eluates may be less cytotoxic than the tested material itself, and experimental findings based on cellular reactions to eluates can underestimate a material's unfavorable effects on cells in vitro [22]. In the present study, therefore, the tested materials were placed in plates into which the cells were seeded and incubated so as to facilitate direct contact between the cells and the specimens, thus simulating the direct contact between the materials and sulcular or LJE cells that would occur in vivo.

The 24-h period for evaluation was chosen as it allowed a sufficient number of cells to adhere to the specimen surfaces to ensure reliability of the results; a pilot study conducted before testing showed that little cell division had occurred by $24 \mathrm{~h}$, as epithelial cell proliferation usually starts

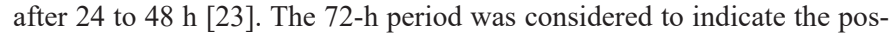
sible cytotoxic effects of the materials, as used in previous studies [3,12].

The results of the present study showed that the type of material significantly affected the viability of gingival epithelial cells; Bulk Flow and Activa showed the highest cell viability values while HV-GIC and RMGI had the lowest values; therefore, the first null hypothesis was rejected. In addition, Bulk Flow and Activa showed significant differences between the 24-h and 72-h subgroups in the results of the MTT assay, and root dentin showed such a difference in the TBDE assay, thus partially rejecting the 
second null hypothesis. It has been reported that both the surface characteristics and composition of restorative material can affect the cell-biomaterial interface, including cell attachment, proliferation and subsequent healing of gingival tissues [12]. Previous investigations of the roughness values of tested materials have reported that Bulk Flow had the smoothest surfaces, followed by RMGI and Activa, while HV-GIC had the roughest surfaces $[24,25]$. It has been reported that a smooth surface favors better oral epithelial cell migration with proliferation and expression of adhesion molecules $[3,16,26]$. One possible explanation is that an increase in surface roughness might cause a decrease in the surface area of the cells. Since spreading of cells is an active process, ridges and troughs in the substrate present a physical barrier to the progression of migrating cells, thus preventing the formation of focal adhesions that are important for cell viability [27]. Moreover, Pendegrass et al. [26] have observed that smooth substrates support monolayers of flatter well attached cells compared to the rounded phenotypes that adhere more loosely to rougher surfaces. The respective morphology of these cell populations was indicative of their proliferative capacities [26,27], supporting the inverse relationship between surface roughness and cell viability and proliferation. These previous findings might explain why Bulk Flow showed the highest cell viability values in both assays.

A number of studies have reported the cytotoxicity of resin composite materials $[2,21,27,28]$; in many cases it seemed that the polymerization process was incomplete and that leaching of unbound monomers from the resin surface was inevitable, particularly during the initial few days. The release of initiators from the organic resin or metal ions from the inorganic filler may induce short-term and long-term adverse tissue reactions [29]. As monomers constitute the main part of a resin matrix, they may represent the largest risk for biotoxic effects and weakening of mechanical properties upon elution [30]. Among different monomers and co-monomers of resin composite matrix, triethyleneglycol dimethacrylate (TEGDMA) and 2-hydroxy-ethyl methacrylate (HEMA) have been shown to be highly cytotoxic and allergenic [2,21,31]. These monomers have been reported to induce apoptosis of both human gingival fibroblasts and epithelial cells in vitro $[2,21]$. Besides its favorable smooth topography, absence of both cytotoxic monomers in the composition of Bulk Flow might explain the cytocompatibility found in this study. The current study finding is consistent with that of Kamalak et al. [28], who compared the same type of flowable bulk fill used in this study with other flowable bulk fill resin composites, and found that Bulk Flow was more biocompatible than other materials, even after $72 \mathrm{~h}$ of incubation.

The MTT assay showed that cell viability in the Bulk Flow group was significantly increased at the end of 72-h incubation period. When a test material and the cells incubated on it in vitro continue to proliferate over time, the material is considered to be non-cytotoxic [31]. Indeed, Alshali et al. [30] reported that the amount of monomers eluted from Bulk Flow was sub-cytotoxic, even after 3 months of storage in water and artificial saliva. Şişman et al. [31] found higher cell viability after 14 days for the same type of bulk fill, but with a paste-like consistency. Conversely, Demirel et al. [29] reported a significant decline in cell viability after $72 \mathrm{~h}$ for material of the same type and with a similar consistency. As only a few studies have evaluated the cytotoxicity of bulk fill dental composite materials [29], it is difficult to compare the results because of the wide variation in experimental conditions such as the cytotoxicity test method, cell type, and cell-material contact method employed.

Although RMGI had lower roughness values than Activa [24], the latter was associated with significantly higher cell viability than RMGI, which showed the lowest values among the tested materials. This could have been related to the respective compositions of the materials. Bioactive materials promote the release of $\mathrm{Ca}^{2+}$ ions, which have mitogenic effects on cells. In agreement with the present findings, López-García et al. [32] and Vicente et al. [33] both reported significantly better biocompatibility, cell adhesion, migration and morphology for Activa than for other glass ionomer-based materials they tested. They suggested that calcium and phosphorus released as a result of degradation of the bioactive glass in Activa might have favorable effects on cell viability and proliferation. In addition, the absence of HEMA [32,33], with its established cytotoxicity effect, in Activa could have accounted for the latter's better biocompatibility relative to RMGI.

It has been reported that the cell irritant and cytotoxicity of RMGI are due to its HEMA content [22]. In accordance with the present findings,
Michel et al. [22] observed that RMGI had significantly stronger cytotoxic effects on both fibroblasts and osteoblasts in comparison with calcium silicate materials. They suggested that this might have been due to leaching of potentially cytotoxic components from RMGI, even after chemical setting [22]. Indeed, Imazato et al. [34] concluded that bisphenol A-glycidyl methacrylate (Bis-GMA)/TEGDMA-based composite resin was more cytocompatible and suitable for proliferation of mesenchymal cells than HEMA-containing RMGI.

Kanjevac et al. [9] have reported that fluoride release has a significant cytotoxic effect through inhibition of cell growth, proliferation, mitochondrial activity and protein synthesis, and induction of programmed cell death. Other authors have also confirmed that high concentrations of $\mathrm{F}$ ion released from glass ionomer-based materials in a wet environment may adversely affect cell metabolism or DNA synthesis [35]. This may also explain the lower cell viability associated with HV-GIC than with Bulk Flow or Activa, despite the lack of monomers in its composition [36]. Although RMGI, HV-GIC and Activa have been reported to release fluoride $[34,35]$, the mode of fluoride release differs between glass ionomers and bioactive glass [33]. It has been reported that fluoride release from RMGI and HV-GIC shows an "initial burst" during the first $24 \mathrm{~h}$ followed by a substantial reduction in the following 2-3 days [37]. However, the release of fluoride from materials containing bioactive glass begins to fall in the first few hours and then remains constant or increases [37]. Fluoride in glass ionomers is released through the hydrolysis of Al-O-Si links, particularly below $\mathrm{pH}$ 6. Its release from bioactive glasses results from the degradation of bioactive glass particles, which also release calcium and phosphorus [38]. The solubility rate of the RMGI and uncoated HV-GIC in a wet environment was found to increase during the first $24 \mathrm{~h}$ after mixing due to incomplete maturation of the material's gel matrix, making the material very sensitive to moisture and allowing easy leaching of the free ion contents [39]. These previous data suggest that a high amount of fluoride might have been released during the first $24 \mathrm{~h}$ of incubation in the RMGI and HV-GIC groups, and may explain their poor cytocompatibility in comparison to Activa, which also releases fluoride. After $72 \mathrm{~h}$ of incubation, however, cell viability increased in all of the groups.

Although the primary aim of this study was to compare the viability of gingival epithelial cells adhering to different restorative materials that are usually placed subgingivally, some comments regarding the control groups are warranted. The root dentin group showed higher cell viability than proximal enamel regardless of the incubation period. As it appears that no previous study has evaluated the cytotoxicity of restorative materials using human proximal enamel or root dentine as a control, one potential explanation is that enamel is usually in contact with both the sulcular epithelium and part of the junctional epithelium, and the former does not truly adhere to the enamel via hemidesmosomes. However, root dentin is in contact with only the junctional epithelium, and true adhesion between the two via hemidesmosomes usually develops under normal healthy conditions. Accordingly, root dentin may be more conducive than enamel to epithelial cell viability and proliferation through preservation of the tight epithelial attachment seal.

It should be recognized that the present in vitro study had certain limitations. Only a single and established cell line was used, serving merely as a general and preliminary assessment. Furthermore, cell imaging using microscopy would have allowed investigation of the cell distribution and morphological changes occurring during direct incubation on the investigated materials. In addition, leaching of monomers from the tested materials was not analyzed, and the components that influenced the biocompatibility of these materials were not investigated, even though they might have impacted the results.

Most cytotoxicity tests for the tested materials are performed using pulp fibroblasts, gingival fibroblasts, cells obtained from bovine dental papilla, odontoblast-like cells obtained from mice, and human dental pulp stem cells [31]. The factors involved in the adhesion of those cells to material surfaces are completely different from those of gingival epithelial cells [23]. Therefore, further investigation of the interactions of different epithelial cells with dental restorative materials that are usually applied subgingivally is warranted, especially in the long term. As this was an in vitro study using cultured cells, caution is warranted when interpreting the data in a clinical context. The periodontal long-term response of these materials when placed subgingivally remains to be confirmed by clinical 
studies. Within the limitations of the present study, it may be concluded that - in terms of biological acceptability - Bulk Flow followed by Activa is more suitable for subgingival restorations and establishing contact with the sulcular and junctional epithelium than glass ionomer-based materials, especially those containing HEMA. Although significant differences between the 24-h and 72-h subgroups were found only for Bulk Flow, Activa and root dentin, all of the materials showed an increase in cell viability after $72 \mathrm{~h}$ in comparison to $24 \mathrm{~h}$, indicating their possible safety and biocompatibility when placed under gingival tissues.

\section{Acknowledgement}

The authors are grateful to Ahmed A. Emam, assistant lecturer in Biochemistry, Medical and Experimental Research Center, Mansoura University, Egypt, for performing the MTT and TBDE assays.

\section{Conflicts of interest}

The authors have no conflicts of interest to declare. The authors alone were responsible for the content and writing of the manuscript.

\section{References}

1. Veneziani M (2010) Adhesive restorations in the posterior area with subgingival cervical margins: new classification and differentiated treatment approach. Eur J Esthet Dent 5, $50-76$.

2. Boloori E, Schoenmaker T, Kleverlaan CJ, Loos BG, de Vries TJ (2020) Gingival epithelium attachment to well- or partially cured resin composites. Eur Cell Mater 40, 259-275.

3. Giannasi C, Pagni G, Polenghi C, Niada S, Manfredi B, Brini AT et al. (2018) Impact of dental implant surface modifications on adhesion and proliferation of primary human gingival keratinocytes and progenitor cells. Int J Periodontics Restorative Dent 38, 127-135.

4. Welbury RR, Murray JJ (1990) A clinical trial of the glass-ionomer cement-composite resin "sandwich" technique in Class II cavities in permanent premolar and molar teeth. Quintessence Int 21, 507-512.

5. Dietschi D, Spreafico R (1998) Current clinical concepts for adhesive cementation of toothcolored posterior restorations. Pract Periodontics Aesthet Dent 10, 47-54; quiz 56.

6. Issa Y, Watts DC, Brunton PA, Waters CM, Duxbury AJ (2004) Resin composite monomers alter MTT and LDH activity of human gingival fibroblasts in vitro. Dent Mater 20, 12-20.

7. Catauro M, Bollino F, Papale F, Gallicchio M, Pacifico S (2015) Influence of the polymer amount on bioactivity and biocompatibility of $\mathrm{SiO}_{2} / \mathrm{PEG}$ hybrid materials synthesized by sol-gel technique. Mater Sci Eng C 48, 548-555.

8. Roggendorf MJ, Krämer N, Appelt A, Naumann M. Frankenberger R (2011) Marginal quality of flowable 4-mm base vs. conventionally layered resin composite. J Dent $39,643-$ 647.

9. Kanjevac T, Milovanovic M, Volarevic V, Lukic ML, Arsenijevic N, Markovic D et al. (2012) Cytotoxic effects of glass ionomer cements on human dental pulp stem cells correlate with fluoride release. Med Chem 8, 40-45

10. Benetti AR, Michou S, Larsen L, Peutzfeldt A, Pallesen U, Van Dijken JWV (2019) Adhesion and marginal adaptation of a claimed bioactive, restorative material. Biomater Investig Dent 6, 90-98.

11. Francois P, Vennat E, Le Goff S, Ruscassier N, Attal JP, Dursun E (2019) Shear bond strength and interface analysis between a resin composite and a recent high-viscous glass ionomer cement bonded with various adhesive systems. Clin Oral Investig 23, 2599-2608.

12. Forster A, Ungvári K, Györgyey Á, Kukovecz Á, Turzó K, Nagy K (2014) Human epithelial tissue culture study on restorative materials. J Dent 42, 7-14.

13. Blattes GBF, Mestieri LB, Böttcher DE, Fossati ACM, Montagner F, Grecca FS (2017) Cell migration, viability and tissue reaction of calcium hypochlorite based-solutions irrigants: an in vitro and in vivo study. Arch Oral Biol 73, 34-39.

14. McGinley EL, Coleman DC, Moran GP, Fleming GJ (2011) Effects of surface finishing conditions on the biocompatibility of a nickel-chromium dental casting alloy. Dent Mater 27, 637-650.

15. Noguchi S, Ukai T, Kuramoto A, Yoshinaga Y, Nakamura H, Takamori Y et al. (2017) The histopathological comparison on the destruction of the periodontal tissue between normal junctional epithelium and long junctional epithelium. J Periodontal Res 52, 74-82.

16. Scheideler L, Rupp F, Wendel HP, Sathe S, Geis-Gerstorfer J (2007) Photocoupling of fibronectin to titanium surfaces influences keratinocyte adhesion, pellicle formation and thrombogenicity. Dent Mater 23, 469-478.

17. Andersson-Wenckert IE, van Dijken JW, Kieri C (2004) Durability of extensive Class II open-sandwich restorations with a resin-modified glass ionomer cement after 6 years. Am J Dent 17, 43-50.

18. Kielbassa AM, Philipp F (2015) Restoring proximal cavities of molars using the proximal box elevation technique: systematic review and report of a case. Quintessence Int 46, 751764.

19. Czasch P, Ilie N (2013) In vitro comparison of mechanical properties and degree of cure of bulk fill composites. Clin Oral Investig 17, 227-235.

20. Illeperuma RP, Park YJ, Kim JM, Bae JY, Che ZM, Son HK et al. (2012) Immortalized gingival fibroblasts as a cytotoxicity test model for dental materials. J Mater Sci Mater Med 23, 753-762.

21. Tamilselvam S, Divyanand MJ, Neelakantan P (2013) Biocompatibility of a conventional glass ionomer, ceramic reinforced glass ionomer, giomer and resin composite to fibroblasts: in vitro study. J Clin Pediatr Dent 37, 403-406.

22. Michel A, Erber R, Frese C, Gehrig H, Saure D, Mente J (2017) In vitro evaluation of different dental materials used for the treatment of extensive cervical root defects using human periodontal cells. Clin Oral Investig 21, 753-761.

23. Dorkhan M, Yücel-Lindberg T, Hall J, Svensäter G, Davies JR (2014) Adherence of human oral keratinocytes and gingival fibroblasts to nano-structured titanium surfaces. BMC Oral Health 14,75 .

24. Ismail HS, Ali AI, Abo El-Ella MA, Mahmoud SH (2020) Effect of different polishing techniques on surface roughness and bacterial adhesion of three glass ionomer-based restorative materials: in vitro study. J Clin Exp Dent 12, e620-e625.

25. Eren MM, Ozan G, Erdemir U, Vatansever C (2021) Streptococcus mutans adhesion to dental restorative materials after polishing with various systems: a confocal microscopy study. Acta Microsc 30, 53-64.

26. Pendegrass CJ, Gordon D, Middleton CA, Sun SN, Blunn GW (2008) Sealing the skin barrier around transcutaneous implants: in vitro study of keratinocyte proliferation and adhesion in response to surface modifications of titanium alloy. J Bone Joint Surg $\mathrm{Br}$ 90,114-121.

27. Atsuta I, Ayukawa Y, Furuhashi A, Ogino Y, Moriyama Y, Tsukiyama Y et al. (2014) In vivo and in vitro studies of epithelial cell behavior around titanium implants with machined and rough surfaces. Clin Implant Dent Relat Res 16, 772-781.

28. Kamalak H, Kamalak A, Taghizadehghalehjoughi A (2018) Cytotoxic effects of new-generation bulk-fill composites on human dental pulp stem cells. Cell Mol Biol (Noisy-le-grand) 64, 62-71.

29. Demirel G, Gür G, Demirsoy FF, Altuntaş EG, Yener-Ilce B, Kiliçarslan MA (2020) Cytotoxic effects of contemporary bulk-fill dental composites: a real-time cell analysis. Dent Mater J 39, 101-110.

30. Alshali RZ, Salim NA, Sung R, Satterthwaite JD, Silikas N (2015) Analysis of long-term monomer elution from bulk-fill and conventional resin-composites using high performance liquid chromatography. Dent Mater 31, 1587-1598.

31. Şişman R, Aksoy A, Yalçın M, Karaöz E (2016) Cytotoxic effects of bulk fill composite resins on human dental pulp stem cells. J Oral Sci 58, 299-305.

32. López-García S, Pecci-Lloret MP, Pecci-Lloret MR, Oñate-Sánchez RE, García-Bernal D, Castelo-Baz P et al. (2019) In vitro evaluation of the biological effects of ACTIVA Kids BioACTIVE Restorative, Ionolux, and Riva Light Cure on human dental pulp stem cells. Materials (Basel) 12, 3694.

33. Vicente A, Rodríguez-Lozano FJ, Martínez-Beneyto Y, Jaimez M, Guerrero-Gironés J, Ortiz-Ruiz AJ (2021) Biophysical and fluoride release properties of a resin modified glass ionomer cement enriched with bioactive glasses. Symmetry 13, 494

34. Imazato S, Horikawa D, Takeda K, Kiba W, Izutani N, Yoshikawa R et al. (2010) Proliferation and differentiation potential of pluripotent mesenchymal precursor $\mathrm{C} 2 \mathrm{C} 12$ cells on resin-based restorative materials. Dent Mater J 29, 341-346.

35. de Mendonça AA, Souza PP, Hebling J, Costa CA (2007) Cytotoxic effects of hard-setting cements applied on the odontoblast cell line MDPC-23. Oral Surg Oral Med Oral Pathol Oral Radiol Endod 104, e102-e108.

36. Collado-González M, Pecci-Lloret MR, Tomás-Catalá CJ, García-Bernal D, OñateSánchez RE, Llena C et al. (2018) Thermo-setting glass ionomer cements promote variable biological responses of human dental pulp stem cells. Dent Mater 34, 932-943.

37. Al-Eesa NA, Wong FSL, Johal A, Hill RG (2017) Fluoride containing bioactive glass composite for orthodontic adhesives - ion release properties. Dent Mater 33, 1324-1329.

38. Tiskaya M, Al-Eesa NA, Wong FSL, Hill RG (2019) Characterization of the bioactivity of two commercial composites. Dent Mater 35, 1757-1768.

39. Jafarpour D, Mese A, Ferooz M, Bagheri R (2019) The effects of nanofilled resin-based coatings on the physical properties of glass ionomer cement restorative materials. J Dent $89,103177$. 